University of Nebraska - Lincoln

DigitalCommons@University of Nebraska - Lincoln

Educational Psychology Papers and

Publications

Educational Psychology, Department of

December 2001

Conceptual constraints on thinking about genocide

David Moshman

University of Nebraska-Lincoln, dmoshman1@unl.edu

Follow this and additional works at: https://digitalcommons.unl.edu/edpsychpapers

Part of the Educational Psychology Commons

Moshman, David, "Conceptual constraints on thinking about genocide" (2001). Educational Psychology Papers and Publications. 45.

https://digitalcommons.unl.edu/edpsychpapers/45

This Article is brought to you for free and open access by the Educational Psychology, Department of at DigitalCommons@University of Nebraska - Lincoln. It has been accepted for inclusion in Educational Psychology Papers and Publications by an authorized administrator of DigitalCommons@University of Nebraska - Lincoln. 


\title{
Conceptual constraints on thinking about genocide
}

\author{
David Moshman \\ University of Nebraska-Lincoln
}

Our thinking is unavoidably constrained by our conceptual structures. To the extent that we reflect on and reconstruct our concepts, however, we can sharpen our thinking. The first section of this article considers the nature of concepts, highlighting a standard distinction between prototype-based and formal concepts.

Drawing on these insights from cognitive psychology, the second section suggests that the ability to recognize and understand genocides is greatly restricted by Holocaust-based conceptions of genocide. In turn one can enhance one's understanding via the construction and application of formal concepts of genocide.

Extending this argument, I observe in the third section that genocide, however defined, has come to be seen as the ultimate human rights catastrophe, and thus the measure of all such catastrophes. Implicitly or explicitly, we routinely construe and evaluate mass killings, cultural exterminations, ethnic cleansings, political disappearances, religious inquisitions, chattel slavery, and other catastrophic violations of human rights through the lens of genocide. This often illuminates the genocidal aspects of diverse atrocities, but it also hinders and distorts our understanding of matters that cannot and should not be understood only in relation to genocide.

Finally, I consider the scientific and educational implications of the present arguments. By articulating, discussing, coordinating, and reflecting on diverse historical cases and diverse formal criteria for genocide and other human rights catastrophes, and by encouraging students to do so as well, we can foster the construction of defensible formal conceptions and an accompanying consciousness about the nature and limits of those conceptions. We cannot escape the constraints inherent in conceptual thought, but we can always transcend the limitations of our current concepts.

\section{The nature of concepts}

In the normal course of perceiving and interpreting events, our concepts are, for the most part, invisible to us. Rather than reflecting on them, we see the world through them. In fact, it is only through concepts that we are able to identify and make sense of the various aspects of the world. What appear to us as objective representations imposed on our minds by reality itself are always in large part a function of the 
network of conceptions to which we have assimilated that reality. Thus, the nature of our concepts to a large degree determines not only our subjective interpretations but even our most elementary, and seemingly objective, observations and categorizations.

The unavoidable subjectivity of conceptual thought, however, does not entail a radical relativism that dismisses objectivity and truth as illusions. Despite their intrinsic subjectivity, our observations and interpretations are also a function of realities outside our minds. Although we cannot directly represent simple and absolute truths about the world, neither are we limited to illusions generated by arbitrary concepts. Perception is a joint function of the realities around us and the conceptions to which we assimilate those realities. Objectivity is not an achievable end but it remains an important epistemic ideal that can be approached by coordinating, reflecting on, and reconstructing our conceptual structures (Moshman, 1998, 1999).

Given the crucial importance of concepts to perception, knowledge, thinking, and development, it is not surprising that cognitive and developmental psychologists have devoted much time and energy to the study of human conceptual structures (Case, 1998; Reed, 2000; Rosser, 1994). An important consideration in such work, and one that is central to the present analysis, is a distinction between formal and prototype-based concepts.

Formal concepts are defined on the basis of a set of necessary and/or sufficient conditions. To be a square, for example, a figure must have precisely two dimensions, four equal sides, and four right angles. Formal concepts, then, foster sharp categorizations. A given figure either is or is not a square. All squares, moreover, regardless of size or color, are equally square.

Prototype-based concepts, on the other hand, are defined on the basis of prototypical instances. Thus, although robins and ostriches are both birds, people see robins as better exemplars of the concept "bird." Ostriches are less bird-like. Moreover, although biologists have no doubt that ostriches are birds, there is room for disagreement about how to classify archaeopteryx and other transitional forms. To the extent that a concept is prototype-based, there are likely to be marginal cases that are not sufficiently like the prototype to fit clearly in the same category but not sufficiently different to fall clearly outside that category.

Human conceptual structures are undoubtedly too complex to be fully understood in terms of a simple distinction between formal and prototype-based concepts. Nevertheless, as we will now see, such a distinction is useful in understanding how people perceive and think about genocide.

\section{Conceptual constraints on thinking about genocide}

The primary conceptual constraint on thinking about genocide, I argue, is the dominance of a Holocaust-based conception of genocide. The problem is not that the Holocaust, rather than some other genocide, has been taken to be prototypical. Given that every genocide is unique, any prototype-based concept of genocide will distort 
one's understanding of some genocides as it filters them through whatever genocide taken as central and defining. The challenge, I conclude, is not to replace the Holocaust with some other genocide as the measure of all genocides, but rather to replace a Holocaust-based concept of genocide with an alternative conception that relates all genocides to each other via a set of formal criteria.

\section{Holocaust-based conceptions of genocide}

It has come to be understood that by the Holocaust (with a capital $\mathrm{H}$ ) we mean a particular historical event and not just anything that might be called a holocaust (Petrie, 2000). The specific term Holocaust has both a narrow and a broader meaning. In the narrow sense, the term refers to the Nazi Judeocide, the deliberate and systematic killing of five to six million Jews by Nazi Germany during the course of World War II. In the broader sense, the Holocaust encompasses Nazi efforts to eliminate Gypsies, Poles, homosexuals, the disabled, and others whose elimination served ideological goals distinct from the war effort.

The Nazi Judeocide, however, is central even to this broader sense of the Holocaust. In a December 2000 letter, for example, the US Holocaust Memorial Museum urged potential new members "to help remember and memorialize the six million Jews and millions of others who died in the Holocaust." The Holocaust here includes more than the six million Jews, but no other victims are specified or counted. Even to the extent that it extends beyond the Nazi Judeocide, the Holocaust has a prototype-based internal structure in which the Nazi Judeocide is taken as central and defining (Johnson and Rittner, 1996).

Whatever the scope and internal structure of the Holocaust, the key consideration for present purposes is the relation of the Holocaust to the concept of genocide. That relation is for most people, including scholars and educators, clear and simple: the Holocaust is widely construed as the prototypical instance of genocide.

To construe the Holocaust as prototypical is not to say that it is typical. On the contrary, it is almost universally seen as extraordinary. A substantial scholarly literature is devoted to demonstrating that the Holocaust was and remains unique in history(Bauer, 1996; Katz, 1998). Some theorists, recognizing that every genocide is unique, pronounce the Holocaust to be "uniquely unique" (Heinsohn, 2000, p 424).

This purported exceptionality (for critiques, see Churchill, 1997; Fein, 1993; Stannard, 1998) is exactly what makes the Holocaust the archetypal and defining member of the greater concept that includes it, the standard against which all other genocides, and purported genocides, are measured. The Holocaust was "the most shocking event of the twentieth century"(Goldhagen, 1996, p. 4), the "most terrible event in modern history" (Weinberg, 1993, p. xiv), "a global attack on Western civilization itself"(Bauer, 1996, p.14).It was the "ultimate expression" (Strom and Parsons, 1982, p.1) of genocide. "[X]enophobic propensities reached their zenith in the twentieth century, when Hitler's Nazi regime perpetuated [sic] the most extensive 
effort at genocide in history" (Solomon, Greenberg and Pyszczynski, 2000, p. 200). "[O]nly in the case of Jewry under the Third Reich was such all-inclusive, noncompromising, and unmitigated murder intended" (Katz, 1998, pp. 19-20). Others had broken the commandment "Thou shalt not kill," but Hitler "was irreducibly distinct from other mega-murderers by abrogating it" (Heinsohn, 2000, p. 425). In a word, "[t]he Nazi regime was the most genocidal the world has ever seen" (Mann, 2000, p. 331).

Such claims are so standard in the Holocaust literature that even theorists and researchers justly known for major contributions to the comparative study of genocide occasionally slip into this sort of hyperbolic rhetoric. As "the ultimate ideological genocide" (p. 323), argued Chalk and Jonassohn (1990), "the Holocaust stands alone in the history of the West and in the history of genocide" (p. 325). Its special characteristics, concludes Charny (1994, p. 72), "have afforded the Holocaust a timeless meaning and a deserved position as the archetypal event of mass murder in human history."

A particularly good example of the Holocaust-based conceptual structure of genocide is the name of the first academic journal ever devoted to the study of genocide: Holocaust and Genocide Studies. Why not just "Genocide Studies"? Why this "Apples and Fruit" approach (Huttenbach, 1999, p. 9)? The answer is that genocide studies consist, in the standard view, of the study of the Holocaust and other genocides. The title of the journal represents the core conceptualization of the field.

Consistent with this Holocaust-based concept of genocide, the content of Holocaust and Genocide Studies is overwhelmingly focused on the Holocaust. In the period 1997 through 2000 (Vols. 11-14), out of a total of 53 published articles, there were 48 that focused exclusively on the Holocaust. Of the remaining five, two addressed related oppressions of Jews during World War II, one addressed the relation of the Holocaust to other genocides, one addressed the Turkish extermination of the Armenians during World War I, and one addressed a set of related Anatolian genocides.

This focus on the Holocaust is not simply an editorial bias of a particular journal; rather, it represents the state of the field. Although scholars, writers, and activists have addressed dozens of major genocides (Andreopoulos, 1994; Chalk and Jonassohn, 1990; Charny, 1994; Churchill, 1997; Des Forges, 1999; Fein, 1993; Gourevitch, 1998; Hovannisian, 1999; Jonassohn and Bjornson, 1998; Melson, 1998; Moses, 2000; Scherrer, 1999; Stannard, 1992; Tatz, 1999), the Holocaust is by far the most extensively researched. Even when theorists of genocide attempt to address general issues rather than the specifics of a particular case, they routinely take the Holocaust as central to their analysis (Lerner, 1992; Staub, 1989).

At a popular level, the Holocaust is surely the best-known genocide in the world. In the United States, for example, there are seven major Holocaust museums, including the government-supported US Holocaust Memorial Museum, and systematic education about the Holocaust is required or recommended by at least 17 states (Finkelstein, 2000). Holocaust programs and curricula abound (Haynes, 1998; Stephens et al., 1995; Strom and Parsons, 1982). 
In stark contrast, there is to my knowledge no major museum or curriculum dedicated to any other genocide, not even the genocides committed against many of the indigenous peoples of what is now the United States (Churchill, 1997; Stannard, 1992). To the extent that other genocides are considered at all, they can only be understood and discussed within a Holocaust-based conception of genocide. We may thus posit that the popular concept of genocide, and to a large extent the scholarly conception as well, is Holocaust-based. We think more about the Holocaust than about any other genocide, and we understand other genocides by analyzing their similarities to and differences from the Holocaust.

Application of a Holocaust-based concept of genocide, as opposed to one based on some other genocide, substantially determines what events are construed as genocidal. Every major historical event is a unique result of multiple intentions, choices, actions, structures, and forces at individual and collective levels. If our concept of genocide is prototype-based, we determine whether some event or set of events constitutes genocide on the basis of its similarities to and differences from what we have taken to be the prototypical genocide. Applying a Holocaust-based concept of genocide, in particular, people identify genocides on the basis of whether an event is sufficiently similar to the Holocaust in what they take to be relevant respects. Thus an overlapping but somewhat different set of historical events might have been seen as genocidal if our prototype, instead of the Holocaust, had been, say, the Armenian genocide of World War I (Hovannisian, 1999; Melson, 1998); the Cambodian genocide of the late 1970s (Hannum, 1989; Kiernan, 1994); the Rwandan genocide of 1994 (DesForges, 1999; Gourevitch, 1998); one of the numerous genocides associated with the European conquest of the Americas, Africa, and Australia (Chalk and Jonassohn, 1990; Churchill, 1997; Jonassohn and Bjornson, 1998; Moses, 2000; Stannard, 1992; Tatz, 1999); or any of the myriad other genocides of human history (Andreopoulos, 1994; Chalk and Jonassohn, 1990; Fein, 1993; Jonassohn and Bjornson, 1998; Scherrer, 1999).

Regardless of what genocide we choose as prototypical, moreover, we face the problem that, because prototype-based concepts have fuzzy boundaries, their application is highly subject to a variety of cognitive biases. One of these is a well-documented general tendency to seek and interpret data in such a way as to maintain one's beliefs (Klaczynski, 2000; Moshman, 1998, 1999; Stanovich, 1999). Prototype-based concepts may shrink or expand selectively so as to avoid or reconstrue discomfiting observations.

Given a Holocaust-based concept of genocide, for example, one's political ideology and patriotic commitments can be expected to have substantial influence on what one views as sufficiently like the Holocaust to constitute genocide. To the extent that one is supportive of a given government, for example, one is (a) less likely to perceive ways in which its actions are similar to those of Nazi Germany; (b) less likely to acknowledge the relevance of whatever similarities one does perceive; (c) more likely to perceive ways in which the government's actions differ from those of Nazi Germany; and(d) more likely to highlight the relevance of those differ- 
ences. Analogous problems hold regardless of what genocide serves as the prototype. The combination of a prototype-based concept of genocide with the general cognitive tendency to perceive and interpret evidence in such a way as to maintain one's views renders one less likely to construe the actions of favored governments as genocidal.

Consider, for example, the systematic extermination of the indigenous inhabitants of Australia by Europeans and their descendants. Although today this is seen by most Australians as regrettable, few label this genocide. Genocide means something like the Holocaust, which means death camps. Tatz (1999) summarizes this line of thinking thus: "Clearly there has been no Australian Auschwitz. Clearly, if there was no Auschwitz here, then no genocide occurred here" (p. 316). Similarly, although the European conquest of the Americas has involved deliberate mass killings of countless millions of individuals and has eliminated hundreds of cultures on two continents over more than five centuries, the absence of death camps enables the nations of the Americas to deny that they were founded on genocide and that, in many cases, these genocides are still in progress (Churchill, 1997).

A different selection of the prototypical genocide would yield different conclusions about the genocidal nature of various historical events, but such conclusions would be no more justifiable that those generated by a Holocaust based conception. Suppose, for example, that we construed the European conquest of the Americas as a singular and ultimate set of interrelated genocides. This mega-genocide, we might note, has been deliberately aimed at, and has succeeded in eliminating, hundreds of discrete cultures throughout the Americas. Moreover, it has for the most part been a consensus policy, pursued generation after generation by the governments of multiple colonial and emerging nations, including the United States, regardless of who held political power (Churchill, 1997; Stannard, 1992). With this as our prototype, we might evaluate apparent genocides with respect to the number of cultures eliminated, the duration of the genocidal processes, and the breadth of support for those processes. The Holocaust, from this perspective, might be dismissed as relatively minor, having targeted only a handful of cultures and having ended after just a few years when the Nazi regime was defeated by forces opposed to the genocide.

Such minimization of the Holocaust is obviously indefensible. It is no different, however, than the routine genocide denials that result from taking the Holocaust as unique and/or prototypical (Churchill, 1997; Stannard, 1998). An alternative conception based on, say, the Cambodian genocide would be quite different from anything yet discussed, but it too, if taken as the ultimate conception, would drastically constrain our comprehension. Any prototype-based conception of genocide has the potential to highlight important features of genocide underplayed by conceptions rooted in other prototypes, but no such conception can ever be definitive.

The path beyond a Holocaust-based concept of genocide, then, cannot consist of a search for the one true prototype of genocide. What we need, I suggest, is a conception of genocide based on abstract criteria - a formal conception of genocide. 


\section{Formal conceptions of genocide}

We might enhance our objectivity in addressing genocide if we could replace the standard Holocaust-based conception with one rooted in formal criteria. The elaboration of a formal conception of genocide, however, is no easy task. If we had a definitive list of genocides we might try to determine what they had in common, but how can we prepare such a list unless we already have a definition of genocide? We could prepare a preliminary list on the basis of our intuitions as to what sort of acts are genocidal, but those intuitions may be overly influenced by implicit Holocaustbased (or other prototype-based) conceptions. Moreover, the entire enterprise of devising criteria for genocide may be influenced by self-serving motivations to classify, or not classify, particular historical events as genocidal.

Despite these difficulties, the value of a formal conception has been widely recognized and a variety of formal definitions of genocide have been proposed. The best known of these is provided by the 1948 United Nations Convention on the Prevention and Punishment of the Crime of Genocide (reprinted in Andreopoulos, 1994; Chalk and Jonassohn, 1990), which defines genocide as

any of the following acts committed with intent to destroy, in whole or in part, a national, ethnical, racial or religious group, as such:(a) Killing members of the group; (b) Causing serious bodily or mental harm to members of the group; (c) Deliberately inflicting on the group conditions of life calculated to bring about its physical destruction in whole or in part; (d) Imposing measures intended to prevent births within the group; (e) Forcibly transferring children of the group to another group.

Among scholars of genocide, this definition is almost universally deemed to be seriously flawed. Kuper (1994), despite reservations, grudgingly acknowledged that the UN conception "provides a workable definitional core for interdisciplinary analysis and application" (p. 31).Others, even more skeptical, have felt compelled to offer alternative definitions and typologies.

Fein (1993), like most theorists, believes the definition of genocide should be broadened to include political, economic, and other victim groups beyond those named in the UN Convention. Other than this, however, her definition is close to that of the UN:

Genocide is sustained purposeful action by a perpetrator to physically destroy a collectivity directly or indirectly, through interdiction of the biological and social reproduction of group members, sustained regardless of the surrender or lack of threat offered by the victim. (p. 24)

Chalk and Jonassohn (1990) agree with Fein that the UN definition is too restrictive with regard to victim groups but prefer to define such groups from the viewpoint of the perpetrator, which may act against groups such as demonic witches or "enemies of the people" that have no objective existence. Moreover, in contrast to both the Convention and Fein, they would limit genocide to mass killings by governments and quasi-governmental authorities: 
Genocide is a form of one-sided mass killing in which a state or other authority intends to destroy a group, as that group and membership in it are defined by the perpetrator. (p. 23, italics in original)

Charny (1994) shares with Chalk and Jonassohn a conception of genocide limited to mass killings, excluding other forms of group extermination recognized as genocidal by the UN and Fein. Charny is appalled, however, that under some definitions "thousands and even millions of defenseless victims of mass murder do not "qualify" as victims of genocide" (p. 64), warning that "the masses of bodies that are not to be qualified for the definition of genocide are dumped into a conceptual black hole, where they are forgotten" (p. 92). Though narrow in its exclusive focus on mass killings, Charny's definition is broader than that of Chalk and Jonassohn in allowing for non-governmental perpetrators and is broader than any of the definitions yet discussed in that it deletes the requirement of intent and encompasses lethal acts that were not aimed at any definable group, real or imaginary:

Genocide in the generic sense is the mass killing of substantial numbers of human beings, when not in the course of military action against the military forces of an avowed enemy, under conditions of the essential defenselessness and helplessness of the victims. (p. 75)

Churchill (1997) provides an especially detailed analysis of how political accommodations and Holocaust-based conceptions have compromised both the UN definition and the efforts of scholars. Looking back to the original work of Raphael Lemkin, originator of the term "genocide," Churchill proposes that genocide is "a denial of the right of existence of entire human groups, as homicide is the denial of the right to live of individual human beings" (p. 431).

Genocide, proposes Churchill,

means the destruction, entirely or in part, of any racial, ethnic, national, religious, cultural, linguistic, political, economic, gender, or other human group, however such groups maybe defined by the perpetrator.(p. 432)

Specific genocides reflect various combinations of three primary forms. One of these forms is "Physical Genocide, by which is meant killing members of the targeted group(s) ..." (p. 432). A second is "Biological Genocide, by which is meant the prevention of births within the target group(s) ..." (p. 433). The third is

Cultural Genocide, by which is meant the destruction of the specific character of the targeted group(s) through destruction or expropriation of its means of economic perpetuation; prohibition or curtailment of its language; suppression of its religious, social or political practices; destruction or denial of access to its religious or other sites, shrines, or institutions; destruction or denial of use and access to objects of sacred or sociocultural significance; forced dislocation, expulsion or dispersal of its members; forced transfer or removal of its children, or any other means. (p. 433)

Churchill carefully denies that any of these three forms is intrinsically more grave a crime than any other, even in those cases where they can be distinguished, but he 
does not deny that some perpetrators of genocide are more culpable than others. Pursuing the analogy of genocide to murder, he distinguishes four degrees of genocide, the most serious of which is "Genocide in the First Degree, which consists of instances in which evidence of premeditated intent to commit genocide is present" (p. 434).

Many other definitions and typologies of genocide exist in the literature (Horowitz, 1997; Rummel, 1994; Scherrer, 1999; for reviews, see Chalk and Jonassohn, 1990; Churchill, 1997; Fein, 1993). The process of articulating, justifying, criticizing, coordinating, and reconstructing such conceptions may lead to some measure of definitional agreement and thus to some measure of consensus in identifying cases of genocide in history and recognizing genocides in the future. Even without agreement on a particular conception, moreover, discussion and reflection with regard to multiple definitions and typologies may yield greater objectivity in the identification and analysis of genocides by directing attention to a variety of relevant considerations. As we will now see, however, formal conceptions have limitations of their own.

\section{Conceptual constraints on thinking about catastrophic violations of human rights}

Holocaust-based conceptions of genocide, I have argued, have hindered our ability to recognize and understand other genocides. Extending the analysis, I argue in this section that genocide-based conceptions of human rights catastrophes have hindered our ability to recognize and understand other catastrophic violations of human rights. The solution to this problem, however, lies not in reliance on some particular formal definition and typology of human rights catastrophes but rather in greater consciousness regarding the role of our conceptions in our thinking.

\section{Genocide-based conceptions of human rights catastrophes}

Genocide is routinely taken to be "the absolute crime, the gravest form of crime against humanity" (Ternon, 1999, p. 238). As "the most barbaric crime"(Scherrer, 1999, p. 14), it constitutes "the ultimate human rights violation" (Jonassohn and Bjornson, 1998, p. 98). In both popular and scholarly discourse, statements of this sort are widely accepted as "self-evident" (Jonassohn and Bjornson, 1998, p. 98)so obviously true that they require no justification.

I suggested earlier that the title of the journal Holocaust and Genocide Studies reflects a Holocaust-based conception of genocide. Analogous to Holocaust and Genocide Studies, at the next higher level of abstraction, is the title of Jonassohn and Bjornson's (1998) Genocide and Gross Human Rights Violations, an important compendium of theory, methodology, and case studies.

Why did the authors call this book Genocide and Gross Human Rights Violations? Why not simply "Gross Human Rights Violations"? Surely genocide is included in that category. The short answer, I think, is that genocide, universally taken 
to be the ultimate evil, lies at the core of what the book is about. To represent accurately the scope of the book, the term genocide needs to be in the title.

In that case, however, why not just call the book Genocide? Jonassohn and Bjornson (1998) suggest that this would be excessively and arbitrarily restrictive. Choosing historical cases for discussion in the book would require that these cases meet some definition of genocide. Given the diverse definitions of genocide in the literature, however, what counts as genocide varies substantially depending on what definition one uses. The authors explain that the book's title "signifies the plan to include in our analysis many cases that may violate one or another definition-including our own-while meeting some of the terms of most of them" (p. xiii).

This expanded plan for the book suggests that genocide lies at the core of a larger concept, a concept with no name and no clear boundaries. The concept of genocide can be extended to define a larger category of which it is a part. That larger category, it appears, has a prototype-based structure with genocide at its core. It consists of genocide plus a vaguely characterized set of quasi-genocidal phenomena, phenomena sufficiently like genocide to be classified with it in the unnamed and illdefined larger category of "gross human rights violations." The title Genocide and Gross Human Rights Violations, then, communicates what the book is about as accurately as any possible brief title could do.

The dilemma for Jonassohn and Bjornson, it appears, is that their book is intended to address an important category of social and historical phenomena that has yet to be adequately conceptualized and named. If we are able to reconstruct our conceptualizations we may find words to communicate more precisely about these matters in the future. For the time being, however, we can only communicate on the basis of our existing concepts and terminology. Thus we face the conceptual difficulty of communicating about a subject larger than genocide for which we have no name.

Genocide, then, is prototypical in the sense that it anchors and defines the larger category of which it is a part. In the realm of mass atrocities, genocide is conceptualized as the evil beyond all others, the ultimate measure of all human rights violations.

This construal of genocide as the ultimate crime greatly raises the stakes with regard to the identification of genocides. If genocide is the gravest form of crime against humanity, then many catastrophic violations of human rights, including massive ethnic cleansings, extended religious inquisitions, coordinated political disappearances, systematic programs of torture, and multigenerational chattel slavery, are less grave, unless it can be shown that they meet some set of criteria for genocide. Even some mass killings and cultural exterminations may fail to qualify as genocidal depending on one's conception. Definitions, in other words, will substantially determine who has committed - and who has been the victim of - the worst of all human crimes.

Once we single out genocide as the worst of all crimes, then, various groups and governments and their political supporters and opponents have strong incentive to 
apply, or not apply, this label to various historical events. Some will perceive ways that human rights atrocities of special concern to them are sufficiently genocidal to be classified among the worst of all crimes. Others will argue that these historical events are perhaps regrettable but far from genocidal.

Political pressures inevitably influence determinations of whether an event is genocidal, and this is greatly intensified to the extent that genocide is construed as the worst of all crimes. As we saw earlier, formal conceptions of genocide serve a useful role in limiting the ambiguities of prototype-based concepts. Is there a role more generally for formal definitions and typologies with regard to catastrophic violations of human rights?

\section{Formal conceptions of human rights catastrophes}

A formal conception of genocide enhances our objectivity in identifying genocides by setting forth an interrelated set of necessary and sufficient conditions for something to be identified as genocidal. In comparison with a prototype-based conception of genocide, a formal conception may make it more difficult to deny the genocidal nature of a historical event. It will not suffices imply to distinguish the alleged genocide in some way from what is taken to be the prototypical genocide. If the formal criteria are met, the event is genocidal.

If the criteria are not met, however, the event is not genocidal, even if it substantially resembles some genuine genocides. Formal criteria place marginal cases on one side or the other of a relatively sharp line of demarcation. Thus, although useful in constraining genocide denial, formal criteria overdifferentiate genocides from other human rights catastrophes. This overdifferentiation of genocides from other human rights catastrophes would be a threat to comprehension of important similarities in any event, but is especially serious given the widespread sense that genocide is the ultimate human rights catastrophe. If genocide is the ultimate crime, then to say something is not genocidal is to suggest that it is less evil, that its perpetrators are less culpable than the perpetrators of genocide, and/or that its victims have been less seriously victimized.

Would distinctions between genocides and non-genocides be more defensible and useful if we had a formal typology of catastrophic human rights violations? Such a typology would provide labels for all types of mass atrocities and relatively objective criteria for assigning such atrocities to the proper categories. Whereas genocide-based conceptions of human rights catastrophes beg the question of the moral relation of genocide to other mass atrocities - what is most genocidal is by definition most evil - a formal conception may enable us to address more objectively the question of whether some mass atrocities are worse than others and, if so, on what basis such comparisons can be made.

There may indeed be value in attempting to devise a formal typology of human rights catastrophes, but we should not expect too much from this endeavor. It is logically possible that there could be a world in which most human rights ca- 
tastrophes fall more or less neatly into some finite number of mutually exclusive categories. Empirically, however, it appears that we do not live in such a world (Jonassohn and Bjornson, 1998). Catastrophic violations of human rights nearly always fall into multiple categories, regardless of what system of categories we use. When human rights are violated at massive levels, they are almost always violated in multiple ways.

With due allowance for the uniqueness of every historical event, we can and should recognize a variety of general labels applicable to human rights catastrophes. Such labels might include mass killing, cultural extermination, ethnic cleansing, political disappearances, religious inquisition, programmatic torture, chattel slavery, and, of course, genocide. But these categories, which are surely not exhaustive, overlap in intricate ways: Mass killings may serve political and/or religious purposes and/or as a means of ethnic cleansing and/or cultural extermination. Cultural extermination may be the desired, expected, or unexpected outcome of ethnic cleansing. Political disappearances and religious inquisitions are routinely linked to systematic programs of torture. Chattel slavery may entail mass killings, programmatic torture, and/or the extermination of cultures. Genocide overlaps the categories of mass killing and cultural extermination in different ways depending on what definition one applies.

In sum, we should not expect to achieve a definitive set of exhaustive, precise, and mutually exclusive categories within which every mass atrocity can be assigned and labeled. A meaningful and useful conception of human rights catastrophes may consist instead of a complex network of prototype-based and quasi-formal concepts within which specific cases can be conceptualized and interrelated.

\section{Is genocide the worst of all crimes?}

I have perhaps finessed the question with which I began the discussion of genocidebased concepts. And I am, perhaps, about to finesse it again. But I am now prepared to be more direct in explaining why an abstract moral evaluation of genocide in relation to other human rights catastrophes is less meaningful than one might expect.

Recall Churchill's (1997) foundational analogy of genocide to murder. Whereas murder denies individual human beings the right of existence, "genocide is a denial of the right of existence of entire human groups" (p. 431). Existence, it might be argued, is prerequisite for anything else. Its denial is thus the denial of everything, the ultimate violation of human rights. It seems to follow that murder is the ultimate crime against an individual and genocide the ultimate crime against a group.

But is every murder worse than every other crime? Suppose you carry out a plan to kill a man who raped your daughter, whereas I kidnap children and torture them for years, leaving them traumatized for life. Only you have committed murder, but it is not obvious that your crime is worse than mine. There may be no general category of crime that qualifies abstractly as worse than ending someone's life, but there 
are particular crimes that, although they fall short of homicide, are arguably worse than particular murders.

Similarly, even if genocide is in some abstract sense the ultimate crime against a social group, it does not follow that every genocide is morally worse than anything that fails to qualify as genocide. Consider, for example, the Atlantic slave trade, a deliberate process that, over a period of centuries, killed millions of individuals and delivered millions more to lives of degradation for themselves and their descendants (Drescher, 1998). Even if we were to determine that this process fails to meet some defensible definition of genocide, perhaps because killing and cultural extermination were not the primary intent, it is far from obvious that the Atlantic slave trade is thereby less evil than any genocide. It is not even obvious that it is less evil than the Holocaust.

More generally, there are at least three reasons for caution in designating some mass atrocities as worse than others. First, as we have seen, there is substantial ambiguity about what qualifies as a genocide. In part this is due to legitimate disagreement among scholars over definitions and criteria. In part it is due to political pressures that lead to gerrymandering of definitions and self-serving interpretations and applications of criteria. In any event, we should be wary of putting too much weight on these classifications in evaluating relative levels of evil or horror.

Second, even if we could agree on a definition of genocide and could be utterly objective in applying it, actual human rights catastrophes, as we have seen, nearly always spill across any set of conceptual categories (Jonassohn and Bjornson, 1998). Genocidal elements can be detected in many or most cases of mass killing, cultural extermination, ethnic cleansing, political disappearances, religious inquisition, group enslavement, and other atrocities. Even if genocide is indeed the ultimate crime, we cannot categorically distinguish acts that meet this threshold of evil from those that do not. Rather, we might use the lens of genocide to bring into focus the most evil and horrifying aspects of a wide variety of crimes against groups.

Finally, at both an individual and collective level, there are fates arguably worse than death. Some individuals and groups, for example, might reasonably consider some circumstances of slavery or torture to be worse than annihilation. Thus, even the abstract notion of the ultimate evil of murder and genocide may be open to question.

Evaluating the relative evil and horror of specific mass atrocities is for the most part an impossible and pointless enterprise. Although genocide is to other crimes against groups as murder is to other crimes against individuals, we should be wary of concluding that genocide is ultimate in some abstract sense and should serve as the measure of other mass atrocities. Genocide-based conceptions of human rights catastrophes may provide useful insights but may also distort our vision. As we have seen, however, formal conceptions are no panacea. What, then, are we to do? 


\section{Conceptualization and consciousness}

As we have seen, prototype-based and formal conceptions each have their uses and limits. Psychological research does not support a general picture of conceptual development as a shift from one type of concept to another (Rosser, 1994). Rather, it appears that conceptual progress consists primarily of achieving higher levels of awareness regarding the nature and limitations of our concepts and, correspondingly, increasing control over their application and coordination (Kuhn, 1999; Moshman, 1998, 1999). With regard to genocide, a shift from Holocaust-based to formal conceptions would, I have argued, represent major progress. In the long run, however, what is most needed is a shift from the automatic application of fixed conceptions to the increasingly deliberate application and coordination of a variety of justifiable conceptions. The goal is not to achieve some final set of correct concepts but rather to enhance our consciousness regarding a variety of conceptual possibilities and the potential interrelations among these. Coordination of multiple definitions and taxonomies may enhance our understanding of complex realities that cannot be subsumed adequately within any simple set of categories.

Consider, for example, what I presented earlier as five major formal conceptions of genocide - those of the United Nations, Fein (1993), Chalk and Jonassohn (1990), Charny (1994), and Churchill (1997). Any of these conceptions is, in my view, far more defensible and useful than any prototype-based concept of genocide. But which of these formal conceptions is best? To choose among them, we must consider a series of dimensions along which they differ:

- Is genocide limited to actions taken against "national, ethnical, racial or religious" groups, as specified in the UN definition, or does it include actions against political, economic, and other groups, as in the other four definitions?

- Is genocide limited to victims defined on the basis of objective group membership (UN, Fein, Churchill) or group membership as perceived by the perpetrator (Chalk and Jonassohn), or does it encompass a wider range of victims (Charny)?

- Is genocide limited to mass killing (Chalk and Jonassohn, Charny), does it include some non-lethal means of group destruction (UN, Fein), or does it encompass all means of cultural extermination (Churchill)?

- Is genocide limited to actions taken by governmental and quasi-governmental authorities (Chalk and Jonassohn) or does it include actions by non-governmental perpetrators (UN, Fein, Charny, Churchill).

- Is genocide limited to acts that are intended to destroy (UN, Fein, Chalk and Jonassohn) or can genocides vary in their degree of intentionality (Charny, Churchill)?

Formal conceptions serve a useful purpose in raising questions of this sort, but may limit our understanding if we feel compelled to provide definitive answers and proceed from these to overly sharp categorizations (Charny, 1994). To take just one example, consider the relation of genocide to cultural extermination. Churchill uses 
the term "cultural genocide" to refer to what a number of theorists-including Fein (1993), Chalk and Jonassohn (1990), and Charny (1994) —have called "ethnocide." This reflects Churchill's conception of genocide as fully encompassing forms of cultural extermination that do not rely on mass killing.

Is ethnocide a type of genocide? If we accept a narrow definition of genocide as mass killing (Chalk and Jonassohn, 1990; Charny, 1994), it follows that many deliberate and successful efforts to eliminate various of the world's human cultures were something different from (and perhaps something less than) genocide. If we define genocide too broadly, however, the term may encompass such a heterogeneous set of phenomena as to be little more than an expression of extreme horror (Chalk and Jonassohn, 1990; Fein, 1993, 1994). Does Churchill (1997) go too far?

In addressing an issue of definition, we should recognize at the start that definitions are social conventions, not empirical truths about the world. Events are not inherently genocidal or not genocidal. It is up to us to determine what we mean by genocide.

That said, it does not follow that any definition is as good, or as arbitrary, as any other. Some definitions may be more meaningful and useful than others, and this depends in part on what the world is like. Thus, although definitions are not truths about the world, there may be empirical and other grounds for preferring one definition to another.

Churchill (1997) provides both a conventional and an empirical argument in support of his case that what others call ethnocide should be construed as a form of genocide. First, he argues that this is faithful to the Raphael Lemkin's original conception of genocide. Others have since narrowed that conception but, given the term's origin, it would not be a radical break with conventional usage to adopt a broader conception. On the contrary, this would be a return to the original meaning of the term.

Second, Churchill argues on empirical grounds that mass killings generally cooccur with other forms of cultural extermination. Thus a distinction between genocide and ethnocide, at least in our world, is not a distinction between two discrete processes but rather between what are typically two aspects of a single process. This does not make the distinction between genocide and ethnocide false but it does suggest that such a distinction is artificial and misleading. Defining genocide to encompass general processes of cultural extermination, including but not limited to mass killings, is not the one true conceptualization but, given the evidence, it seems the most useful.

Personally, I find Churchill's case for this aspect of his definition convincing. More important than recommending Churchill's definition, however, I recommend awareness of the options, arguments, evidence, and choices that led to Churchill's definition of genocide, with full recognition that such consciousness could direct a reasonable person toward a different conceptualization. Progress in our understanding of genocide, I suggest, will come about not only through good choices of definitions but through greater consciousness of our conceptualizations. 
Such consciousness, in fact, may counter some of the disadvantages of settling on a single formal conception. Even if we classify ethnocide as a form of genocide, for example, awareness of the choice we have made may help us remain aware of the threat to conceptual clarity inherent in broad undifferentiated conceptions. Rather than settle for a broad definition of genocide, we may choose (as Churchill does) to create a typology within that definition that recaptures the distinctions others have deemed important.

Correspondingly, adoption of a narrower conception of genocide that excludes non-lethal ethnocides may lead us to ignore or minimize the significance of events that do not qualify as genocide. Consciousness of this choice and its potential consequences, however, may direct our attention toward the similarities and interrelations between ethnocide and genocide, including the possibility of classifying these together as part of some superordinate, and yet to be named, category (Charny, 1994). This raises the possibility that ethnocides and other non-genocides may be no less evil than genocide.

In sum, although some definitions and typologies are more defensible and useful than some others, thinking objectively about these matters is not just a matter of choosing the correct conception. More important than this may be consciousness regarding the nature and justifiability of various conceptual options and the theoretical and practical consequences of our choices among these options.

Consider, for example, the following sets of events:

(a) the massacres of all inhabitants of hundreds of villages in El Salvador, Guatemala, and elsewhere by US-supported battalions during the Latin American "dirty wars" of the 1970s and 1980s (Danner, 1994);

(b) the political "disappearances," tortures, and killings of tens of thousands of students and other young adults in Argentina, Chile, and elsewhere during this same period (Bouvard, 1994; Guest, 1990);

(c) the deadly exploitation of millions of Africans that depopulated the Congo around the turn of the 20th century under the rule of Belgium's King Leopold (Hochschild, 1998);

(d) the deliberate starvation of millions in the centrally orchestrated famines of Stalin's Soviet Union (Chalk and Jonassohn, 1990; Jonassohn and Bjornson, 1998);

(e) the 1989 massacre of thousands of dissident students in China's Tiananmen Square (Charny, 1994);

(f) the Cherokee Trail of Tears and other ethnic cleansings associated with the consolidation and westward expansion of the United States (Churchill, 1997; Stannard, 1992);

(g) the deliberate mass destruction of civilian populations in Dresden, Tokyo, Hiroshima, and Nagasaki during World War II (Fein, 1994; Kuper, 1994); and

(h) the Rape of Nanking (Chang, 1997). 
Depending on what definition we use, we may determine that some of these cases should be called genocides and some not. Such categorizations can be useful, especially when they are made on the basis of objective formal criteria. But what we need most is consciousness of the bases for these categorizations, the various dimensions along which evils of this magnitude can be compared. The point is not to decide that one mass atrocity is worse than some other but to understand their various characteristics and interrelations.

The same considerations hold with regard to students. As noted earlier, education about genocide is typically limited to the Holocaust, "the darkest chapter of our history" (Stephens et al, 1995, p.2), with a few examples, perhaps, of what are taken to be lesser genocides and other violations of human rights. Such curricula instill or reinforce Holocaust-based conceptions of genocide and genocide-based conceptions of human rights, and thus may serve more to obfuscate than to clarify and educate.

Genocide curricula may counter Holocaust-based conceptions by presenting a variety of genocidal and quasi-genocidal events and encouraging students to consider these on the basis of formal definitions and taxonomies. The purpose of a genocide curriculum should not be to indoctrinate students in a particular formal conception of genocide or particular conclusions about what events are or are not genocidal, nor should it be to secure an unshakable commitment to particular courses of action. Rather, genocide curricula should aim to enhance students' consciousness about the various dimensions along which genocides differ from each other and from other catastrophic violations of human rights and about the associated theoretical and practical options and arguments. The intent is not to instill particular conceptions but to enhance students' powers of conceptualization. Our aim should be to foster students' ability to formulate, articulate, and justify defensible views of their own, and to act on the basis of those views.

\section{Conclusion}

The Holocaust, observes Flanzbaum (1999, p. 102), has attained a "cult-like status" that "has been augmented by its use as a touchstone of victimization." It "frequently enters discussions of ethnicity by becoming a measuring stick against which all oppression is compared." Not only does this distort our understanding of genocide, it distorts our understanding of oppression - not to mention our understanding of the Holocaust itself. Through formal criteria and greater consciousness of our conceptualizations, I have argued, we can better comprehend the nature and diversity of human rights catastrophes.

This analysis, some might fear, has the potential to trivialize the Holocaust. To acknowledge other genocides, however, is not to deny the horror of the genocide that has most shocked the conscience of the world. Even if the Holocaust loses its artificially induced special status, it remains what it has always been-a nightmare reality of concentration, starvation, deportation, massacres, ethnic cleansing, slave labor, industrialized mass killings, and deliberate group exterminations, a horror no one will ever fully comprehend. 
But now we know that there are many such horrors, that genocides and other atrocities that defy easy comprehension have occurred all over the world throughout the course of history and continue unabated (Chalk and Jonassohn, 1990; Charny, 1994; Chomsky, 1989; Churchill, 1997; Fein, 1993; Jonassohn and Bjornson, 1998; Rummel, 1994). The Holocaust is both worse than we can ever imagine as well as a small part of a much larger picture.

This is a terrifying vision. The conceptual constraints that restrict our thinking about genocide and other mass atrocities are reinforced by emotional constraints on facing horrors of this sort. Thus we readily reduce the myriad catastrophic violations of human rights to genocide, reduce genocide to the Holocaust, and reduce the Holocaust to a singular event of the past. Through such conceptualizations we contain our initial horror within a righteous sense of moral resolve to see that nothing like the Holocaust ever happens again.

But things like the Holocaust, whether or not we acknowledge them and whether or not we have language to describe them, are happening all the time. It is not clear how much we will ever face, much less teach, about this. What is clear is that our conceptions in this area are grossly inadequate, and that greater consciousness of our conceptualizations is critical for greater understanding.

\section{Note}

* This article evolved from a brief paper presented at Contemporary Forms of Genocide: An International Symposium, University of Nebraska-Lincoln, April, 1996. I am grateful to Ellen McWhirter for insightful and helpful comments on the original paper. Reprint requests and other inquiries should be directed to David Moshman at the Department of Educational Psychology, University of Nebraska-Lincoln, Lincoln, NE 68588-0345, USA; or via email: dmoshman1@unl.edu

\section{Bibliography}

Andreopoulos, G. J., ed. (1994) Genocide: Conceptual and Historical Dimensions (Philadelphia: University of Pennsylvania Press).

Bauer, Y. (1996) "The impact of the Holocaust," Annals of the American Academy of Political and Social Science, Vol 548, pp 14-22.

Bouvard, M. G. (1994) Revolutionizing Motherhood: The Mothers of the Plaza de Mayo (Wilmington, DE: SR Books).

Case, R. (1998) "The development of conceptual structures," in W. Damon, series ed., D. Kuhn and R. Siegler, vol. eds., Handbook of Child Psychology: Vol. 2. Cognition, Perception, and Language, 5th edn. (New York: Wiley).

Chalk, F. and Jonassohn, K. (1990) The History and Sociology of Genocide: Analyses and Case Studies (New Haven, CT: Yale University Press).

Chang, I. (1997) The Rape of Nanking: The Forgotten Holocaust of World War II (New York: Basic Books).

Charny, I. W.(1994) "Toward a generic definition of genocide," in G. J. Andreopoulos, ed., Genocide: Conceptual and Historical Dimensions (Philadelphia: University of Pennsylvania Press). 
Chomsky, N. (1989) Necessary Illusions: Thought Control in Democratic Societies (Boston: South End Press).

Churchill, W. (1997) A Little Matter of Genocide: Holocaust and Denial in the Americas, 1492 to the Present (San Francisco: City Lights Books).

Danner, M. (1994) The Massacre at El Mozote (New York: Random House).

DesForges, A. (1999) Leave None to Tell the Story: Genocide in Rwanda (New York: Human Rights Watch).

Drescher, S. (1998) "The Atlantic slave trade and the Holocaust: a comparative analysis," in A. S. Rosenbaum, ed., Is the Holocaust Unique? Perspectives on Comparative Genocide (Boulder, CO: Westview).

Fein, H. (1993) Genocide: A Sociological Perspective (London: Sage).

Fein, H. (1994) "Genocide, terror, life integrity, and war crimes: the case for discrimination," in G. J. Andreopoulos, ed., Genocide: Conceptual and Historical Dimensions (Philadelphia: University of Pennsylvania Press).

Finkelstein, N. G. (2000) The Holocaust Industry: Reflections on the Exploitation of Jewish Suffering (London: Verso).

Flanzbaum, H. (1999) “The Americanization of the Holocaust," Journal of Genocide Research, Vol 1, pp 91-104.

Goldhagen, D. J. (1996) Hitler's Willing Executioners: Ordinary Germans and the Holocaust (New York: Knopf).

Gourevitch, P. (1998) We Wish to Inform You that Tomorrow We Will Be Killed with our Families: Stories from Rwanda (New York: Picador).

Guest, I. (1990) Behind the Disappearances: Argentina's Dirty War against Human Rights and the United Nations (Philadelphia: University of Pennsylvania Press).

Hannum, H. (1989) "International law and Cambodian genocide: the sounds of silence," Human Rights Quarterly, Vol 11, pp 82-138.

Haynes, S. R. (1998) "Holocaust education at American colleges and universities: a report on the current situation," Holocaust and Genocide Studies, Vol 12, pp 282-307.

Heinsohn, H.(2000) "What makes the Holocaust a uniquely unique genocide?" Journal of Genocide Research, Vol 2, pp 411-430.

Hochschild, A. (1998) King Leopold's Ghost: A Story of Greed, Terror, and Heroism in Colonial Africa (Boston: Houghton Mifflin).

Horowitz, I. L. (1997) Taking Lives: Genocide and State Power (New Brunswick, NJ: Transaction).

Hovannisian, R. G., ed. (1999) Remembrance and Denial: The Case of the Armenian Genocide (Detroit: Wayne State University Press).

Huttenbach, H. R. (1999) "From the editor: apologia rationalis," Journal of Genocide Research, Vol 1, pp 7-10.

Johnson, M. and Rittner, C. (1996) "Circles of Hell: Jewish and non-Jewish victims of the Nazis," Annals of the American Academy of Political and Social Science, Vol 548, pp 123-137.

Jonassohn, K. and Bjornson, K. S. (1998) Genocide and Gross Human Rights Violations: In Comparative Perspective (New Brunswick, NJ: Transaction).

Katz, S. T. (1998) "The uniqueness of the Holocaust: the historical dimension," in A. S. Rosenbaum, ed., Is the Holocaust Unique? Perspectives on Comparative Genocide (Boulder, CO: Westview).

Kiernan, B.(1994) "The Cambodian genocide: issues and responses," in G. J. Andreopoulos, ed., Genocide: Conceptual and Historical Dimensions (Philadelphia: University of Pennsylvania Press).

Klaczynski, P. A. (2000) "Motivated scientific reasoning biases, epistemological beliefs, and theory polarization: a two-process approach to adolescent cognition," Child Development, Vol 71, pp 1347-1366. 
Kuhn, D. (1999) “Metacognitive development," in L. Balter and C. S. Tamis Le-Monda, eds, Child Psychology: A Handbook of Contemporary Issues (Philadelphia: Psychology Press).

Kuper, L. (1994) "Theoretical issues relating to genocide: uses and abuses," in G. J. Andreopoulos, ed., Genocide: Conceptual and Historical Dimensions (Philadelphia: University of Pennsylvania Press).

Lerner, R. M. (1992) Final Solutions: Biology, Prejudice, and Genocide (University Park, PA: Pennsylvania State University Press).

Mann, M. (2000) “Were the perpetrators of genocide 'ordinary men' or 'real Nazis'? Results from fifteen hundred biographies," Holocaust and Genocide Studies, Vol 14, pp 331-366.

Melson, R. F. (1998) “The Armenian genocide as precursor and prototype of twentieth-century genocide, "in A. S. Rosenbaum, ed., Is the Holocaust Unique? Perspectives on Comparative Genocide (Boulder, CO: Westview).

Moses, A. D. (2000) "An antipodean genocide? The origins of the genocidal moment in the colonization of Australia," Journal of Genocide Research, Vol 2, pp 89-106.

Moshman, D. (1998) "Cognitive development beyond childhood," in W. Damon, series ed., D. Kuhn and R. Siegler, vol eds, Handbook of Child Psychology: Vol. 2. Cognition, Perception, and Language, 5th edn (New York: Wiley).

Moshman, D. (1999) Adolescent Psychological Development: Rationality, Morality, and Identity (Mahwah, NJ: Erlbaum).

Petrie, J. (2000) "The secular word HOLOCAUST: scholarly myths, history, and 20th century meanings," Journal of Genocide Research, Vol 2, pp 31-63.

Reed, S. K. (2000) Cognition: Theory and Applications, 5th edn (Belmont, CA: Wadsworth).

Rosser, R. (1994) Cognitive Development (Boston: Allyn and Bacon).

Rummel, R. J. (1994) Death by Government (New Brunswick, NJ: Transaction).

Scherrer, C. P. (1999) "Towards a theory of modern genocide. Comparative genocide research: definitions, criteria, typologies, cases, key elements, patterns and voids," Journal of Genocide Research, Vol 1, pp 13-23.

Solomon, S., Greenberg, J. and Pyszczynski, T. (2000) "Pride and prejudice: fear of death and social behavior," Current Directions in Psychological Science, Vol 9, pp 200-204.

Stannard, D. E. (1992) American Holocaust: The Conquest of the New World (New York: Oxford University Press).

Stannard, D. E.(1998) "Uniqueness as denial: the politics of genocide scholarship," in A. S. Rosenbaum, ed., Is the Holocaust Unique? Perspectives on Comparative Genocide (Boulder, CO: Westview).

Stanovich, K. E. (1999) Who is Rational? Studies of Individual Differences in Reasoning (Mahwah, NJ: Erlbaum).

Staub, E. (1989) The Roots of Evil: The Origins of Genocide and Other Group Violence (Cambridge: Cambridge University Press).

Stephens, E. C., Brown, J. E., and Rubin, J. E. (1995) Learning about ... the Holocaust: Literature and Other Resources for Young People (North Haven, CT: Shoe String Press).

Strom, M. S. and Parsons, W. (1982) Facing History and Ourselves: Holocaust and Human Behavior (Watertown, MA: Intentional Educations).

Tatz, C. (1999) “Genocide in Australia,” Journal of Genocide Research, Vol 1, pp 315-352.

Ternon, Y. (1999) "Freedom and responsibility of the historian: the Lewis affair," in R. G. Hovannisian, ed., Remembrance and Denial: The Case of the Armenian genocide (Detroit: Wayne State University Press).

Weinberg, J. (1993) "From the director," in M. Berenbaum, ed., The World Must Know: The History of the Holocaust as Told in the United States Holocaust Memorial Museum (Washington, DC: United States Holocaust Memorial Museum). 